\title{
Local Glucocorticoid Activation by $11 \beta$-Hydroxysteroid Dehydrogenase 1 in Keratinocytes
}

\section{The Role in Hapten-Induced Dermatitis}

\author{
Mika Terao, Saori Itoi, Sayaka Matsumura, Lingli Yang, Hiroyuki Murota, and Ichiro Katayama
}

From the Department of Dermatology, Graduate School of Medicine, Osaka University, Suita, Osaka, Japan

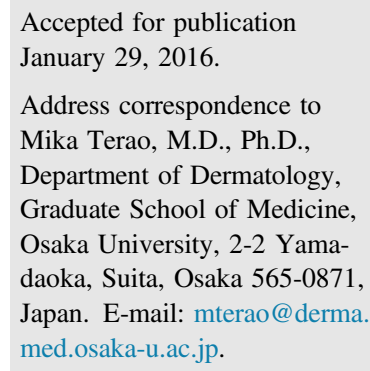

\begin{abstract}
Over the past decade, extra-adrenal cortisol production was reported in various tissues. The enzyme that catalyzes the conversion of hormonally inactive cortisone into active cortisol in cells is $11 \beta$ hydroxysteroid dehydrogenase $1(11 \beta-H S D 1)$. We recently reported that $11 \beta-H S D 1$ is also expressed in keratinocytes and regulates inflammation and keratinocyte proliferation. To investigate the function of $11 \beta$-HSD1 in keratinocytes during inflammation in vivo, we created keratinocyte-specific $11 \beta$-HSD1 knockout (K5-Hsd11b1-KO) mice and analyzed the inflammatory response in models of hapten-induced contact irritant dermatitis. K5-Hsd11b1-KO mice showed enhanced ear swelling in low-dose oxazolone-, 2,4,6-trinitro-1-chlorobenzene (TNCB)-, and 2,4-dinitrofluorobenzene-induced irritant dermatitis associated with increased inflammatory cell infiltration. Topical application of corticosterone dose dependently suppressed TNCB-induced ear swelling and cytokine expression. Similarly in mouse keratinocytes in vitro, corticosterone dose dependently suppressed 2,4,6-trinitrobenzenesulfonic acid-induced IL-1 $\alpha$ and IL-1 $\beta$ expression. The effect of 11-dehydrocorticosterone was attenuated in TNCB-induced irritant dermatitis in K5-Hsd11b1-KO mice compared with wild-type mice. In human samples, 11ß-HSD1 expression was decreased in epidermis of psoriasis vulgaris compared with healthy skin. Taken together, these data suggest that corticosterone activation by $11 \beta-H S D 1$ in keratinocytes suppresses hapten-induced irritant dermatitis through suppression of expression of cytokines, such as IL- $1 \alpha$ and IL-1 $\beta$, in keratinocytes. (Am J Pathol 2016, 186: 1499-1510; http://dx.doi.org/10.1016/j.ajpath.2016.01.014)
\end{abstract}

Glucocorticoids (GCs) are one of the most effective classes of anti-inflammatory drugs and have been in use for more than a half century to treat acute and chronic inflammatory diseases. In dermatology, topical GCs are also often used to treat inflammatory skin diseases. GCs act by exerting an antiinflammatory effect on keratinocytes and skin-infiltrating inflammatory cells.

Cortisol and corticosterone are the endogenous GCs in humans and rodents, respectively. GCs are released in response to various physical stressors and psychological stress. Over the past decade, research has focused on local cortisol/ corticosterone production by de novo synthesis and by an activating enzyme. ${ }^{1}$ Extra-adrenal production/activation of cortisol/corticosterone was reported in tissues such as the colon, heart, and lung. ${ }^{2-8}$ Local cortisol/corticosterone production in the skin by a de novo pathway and by the cortisol-activating enzyme 11 $\beta$-hydroxysteroid dehydrogenase (11 $\beta$-HSD) was also reported. ${ }^{9}$

$11 \beta$-HSD resides in the membrane of the endoplasmic reticulum and catalyzes the interconversion of hormonally active cortisol/corticosterone and inactive cortisone/ 11-dehydrocorticosterone (11DHC) in cells. ${ }^{24-26}$ The enzyme $11 \beta$-hydroxysteroid dehydrogenase 1 (11 $\beta$-HSD1) is widely present in the liver, lungs, adipose tissues, ovaries, and central nervous system.

\footnotetext{
Supported in part by a grant-in-aid for Young Scientists (A) 24689045 and Lydia O'Leary Memorial Foundation.
}

Disclosures: None declared. 
Association of 11 $\beta$-HSD1 with various diseases has been reported. In 2001, Masuzaki et al ${ }^{27}$ reported that transgenic mice overexpressing $11 \beta$-HSD1 in adipose tissue had increased adipose levels of corticosterone and developed visceral obesity that was exaggerated by a high-fat diet. A large number of findings of $11 \beta-\mathrm{HSD} 1$ associated with obesity have been reported since then. 11 -HSD1 is also associated with other diseases, including rheumatoid arthritis, inflammatory bowel disease, polycystic ovary syndrome, and lung disease..$^{8,28-31}$

Functions of $11 \beta-H S D 1$ in healthy skin physiology and disease have also been reported. Expression of $11 \beta-\mathrm{HSD} 1$ is decreased in benign and malignant skin tumors, including seborrheic keratosis, basal cell carcinoma, and squamous cell carcinoma. ${ }^{32}$ In contrast, UVB irradiation increased expression of $11 \beta$-HSD1. ${ }^{33}$ In a mouse model $11 \beta-H S D 1$ negatively regulated the proliferation of keratinocytes and fibroblasts both in vivo and in vitro. ${ }^{16}$ Enhanced wound healing in $11 \beta$-HSD1 knockout (KO) mice was also reported. ${ }^{34}$

We previously initiated an investigation of the effects of $11 \beta-H S D 1$ in skin with the use of $H s d 11 b 1$ null $\left(H s d 11 b 1^{-1-}\right)$ mice; however, the analysis was complicated because the mice showed increased serum corticosterone concentrations, probably because of some compensatory mechanism. ${ }^{35,36}$ Thus, in the current study, we generated keratinocyte-specific $H s d 11 b 1$ $\mathrm{KO}(\mathrm{K} 5-\mathrm{Hs}$ l11bl-KO) mice to investigate the function of $11 \beta-H S D 1$ in keratinocytes and to eliminate the effect on serum corticosterone observed in conventional 11 $\beta$-HSD1 KO mice. We further investigated the expression of $11 \beta-H S D 1$ in psoriasis vulgaris.

\section{Materials and Methods}

\section{Materials}

2,4,6-Trinitrobenzenesulfonic acid (TNBS) and 2,4,6-trinitro1-chlorobenzene (TNCB) were purchased from Nakarai (Kyoto, Japan) and Tokyo Chemical Industry (Tokyo, Japan), respectively. 2,4-Dinitrofluorobenzene (DNFB), oxazolone (OXA), corticosterone, and 11DHC were purchased from Sigma-Aldrich (St. Louis, MO).

\section{Cell Culture}

Isolation and culture of mouse keratinocytes were performed as previously described. ${ }^{16}$ Full-thickness skin harvested from 12-week-old mouse ear and tail was treated with $4 \mathrm{mg} / \mathrm{mL}$ dispase (Gibco; Invitrogen, Paisley, UK) for 1 hour at $37^{\circ} \mathrm{C}$. Next, the epidermis was peeled from the dermis. The epidermis was trypsinized to prepare single cells. The cells were then incubated in EpiLife (Life Technologies, Carlsbad, $\mathrm{CA}$ ) for 6 hours at $37^{\circ} \mathrm{C}$ in an atmosphere of $5 \% \mathrm{CO}_{2}$ in culture dishes precoated with type 1 collagen (Iwaki Glass, Chiba, Japan). Nonadherent cells were washed away with phosphate-buffered saline twice, and adherent cells were cultured for 2 to 3 days in EpiLife. One day before use in experiments culture medium was replaced with cortisol- and phenol red-free EpiLife to eliminate the effect of cortisol.

Mice

Animal care was in strict accordance with the institutional guidelines of Osaka University. All animal experiments were performed with the approval of the Animal Experiments Committee of Osaka University (no. 20-003-0). $H s d 11 b 1^{\text {tm1a/tm1a }}$ mice equivalent to $H s d 11 b 1^{-1-}$ mice were obtained as previously described. ${ }^{35}$ To create $H s d 11 b 1^{\text {floxfflox }}$

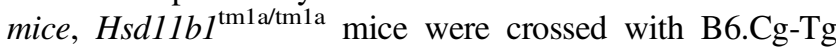
(ACTFLPe)9205Dym/J mice purchased from The Jackson Laboratory (Bar Harbor, ME) to remove the en2SA-IRES-

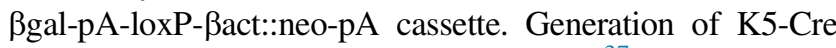
transgenic mice was previously described. ${ }^{37} \mathrm{~K} 5$-Cre trans-

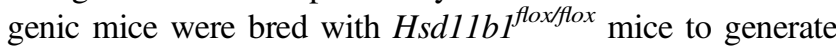
mice that carried the K5-Cre transgene and a floxed $H s d 11 \mathrm{bl}$ allele $\left(\mathrm{K}^{\mathrm{Cre} / \mathrm{O}} ; \mathrm{Hsdll} \mathrm{bl}^{\mathrm{flox/+}}\right)$. These mice were then mated with each other. Offspring that carried $K 5^{C r e / 0} ; H s d l 1 b 1^{\text {floxfflox }}$ and $\mathrm{K}^{\mathrm{CrelO}}$; $\mathrm{Hsdll} \mathrm{bl}^{+/+}$were used for further analyses as K5-Hsd11b1-KO and wild-type, respectively. Generation of $H s d 11 \mathrm{bl}^{-1-}$ mice was described in detail in our previous study. ${ }^{35}$

\section{Histopathologic Analysis}

Samples of normal skin from healthy volunteers were taken with written informed consent. All studies were approved by the ethical committee of Osaka University. Detailed patient demographic characteristics (age, sex, and biopsy site) are described in Supplemental Table S1. Human samples and mouse skin were fixed in $10 \%$ formaldehyde for 24 hours, followed by embedding in paraffin and microtome sectioning. Slides were stained with hematoxylin and eosin. For immunofluorescence analysis, sections were hydrated by passage through xylene and graded ethanols. After antigen retrieval for 10 minutes at $115^{\circ} \mathrm{C}$ in citrate buffer, $\mathrm{pH} 6.0$ (for 11 $\beta$-HSD1) for 7 minutes at room temperature in Proteinase $\mathrm{K}$ (for CD45, Gr-1, F4/80), the slides were blocked with serum-free protein block (Dako-Cytomation, Carpinteria, CA) for 30 minutes, then incubated with primary antibody overnight at $4{ }^{\circ} \mathrm{C}$ (rabbit anti-11ß-HSD1 antibody ab109554; dilution 1:100; Abcam, Cambridge, UK; mouse anti-Keratin 14 antibody ab49806; dilution 1:100; Abcam), followed by secondary antibody (anti-rabbit Alexa Fluor 555, A21428; anti-mouse Alexa Fluor 488, A11001; Invitrogen) and nuclear staining (Hoechst 33342; Invitrogen). For immunohistochemical analysis, sections were hydrated by passage through xylene and graded ethanols. After antigen retrieval for 10 minutes at $130^{\circ} \mathrm{C}$ in citrate buffer, $\mathrm{pH} 6.0$, the slides were incubated in $0.3 \% \mathrm{H}_{2} \mathrm{O}_{2}$ to block endogenous peroxidase activity. The slides were blocked with serum-free protein block (Dako-Cytomation) for 30 minutes and then incubated with rabbit anti-chemokine ligand 8 antibody (Bioss, Woburn, 
MA) overnight at $4{ }^{\circ} \mathrm{C}$, followed by incubation with rabbit anti-11ß-HSD1 antibody, rat anti-CD45 antibody (550539; dilution 1:100; BD Biosciences, San Jose, CA), rat anti-Gr-1 antibody (14593181; dilution 1:100; eBioscience, San Diego, CA), or rat anti-F4/80 antibody (MCA497R; dilution 1:100; $\mathrm{AbD}$ Serotec, Oxford, UK) overnight at $4^{\circ} \mathrm{C}$. After washing with TBS-T (50 mmol/L Tris- $\mathrm{HCl}, \mathrm{pH} 7.6,150 \mathrm{mmol} / \mathrm{L} \mathrm{NaCl}$, and $0.1 \% \mathrm{v} / \mathrm{v}$ Tween-20), slides were developed with the use of the Vectastain ABC kit (Vector Laboratories, Burlingame, $\mathrm{CA})$ and counterstained with hematoxylin. Rabbit and rat IgG served as isotype controls.

\section{Staining Quantification}

Epidermal staining intensity and extent were blindly evaluated by two individuals (M.T. and S.M.). For each specimen, staining index was assessed by multiplying the staining intensity score by the extent of staining score as previously reported. ${ }^{32}$ Staining intensity was graded as follows: 1 , none; 2 , weak; 3 , moderate; 4 , strong. Staining extent was graded as follows: $1,0 \%$ to $24 \%$; $2,25 \%$ to $49 \%$; $3,50 \%$ to $74 \%$; and $4,75 \%$ to $100 \%$. On the basis of our formula, the index ranges from 1 to 16 .

\section{Hapten-Induced Irritant Dermatitis Model}

Both surfaces of the right ear of each mouse was painted with $0.2 \%$ OXA, $0.2 \%$ TNCB, or $0.3 \%$ DNFB in $1: 4$ oil/acetone. Left ear was painted with 1:4 olive oil/acetone as vehicle control. Ear skin was harvested 24 hours after treatment.

\section{RNA Isolation and Quantitative Real-Time PCR}

For collection of samples, full-thickness ear skin, liver, and adrenal gland were harvested and crushed in liquid nitrogen. Total RNA was isolated from cells or tissues with the use of the SV Total RNA Isolation System (Promega, Madison, WI). The product was reverse-transcribed into first-strand cDNA. The expression of IL- $1 \alpha$, IL-1 $\beta$, CXCL1, IL-6, and Hsd11b1 were measured with the Power SYBR Green PCR Master Mix (Applied Biosystems, Foster City, CA) according to the manufacturer's protocol. Relative mRNA levels were normalized to that of hypoxanthine phosphoribosyltransferase (HPRT). Sequence-specific primers were designed as follows: IL1- $\alpha$, sense 5'-TCAAGATGGCCAAAGTTCCT- ${ }^{\prime}$, antisense $5^{\prime}$-CTTCAGAATCTTCCCGTTGC-3'; IL-1 $\beta$, sense $5^{\prime}$-ACCCTGCAGCTGGAGAGTGT-3', antisense 5'-CAAACCGTTTTTCCATCTTCTTCTT-3'; CXCL1, sense 5'-GCCTATCGCCAATGAGCTG-3', antisense $5^{\prime}$-TCTCCGTTACTTGGGGACAC-3'; L-6, sense 5'-CTGATGCTGGTGACAACCAC-3', antisense 5'-CAGAATTGCCATTGCACAAC-3'; Hsd11b1, sense 5'-AAAATTACCTCCTCCCGATCCT-3', antisense 5'-GGCAGCGAGACACTACCTTC- ${ }^{\prime}$; and HPRT, sense 5'-CACAGGACTAGAACACCTGC-3', antisense 5'-GCTGGTGAAAAGGACCTCT-3'. Quantitative real-time PCR (40 cycles of denaturation at $92^{\circ} \mathrm{C}$ for 15 seconds and annealing at $60^{\circ} \mathrm{C}$ for 60 seconds) was run on an ABI 7000 Prism (Applied Biosystems).

\section{Western Blot Analysis}

Mouse skin samples were crushed in liquid nitrogen and solubilized at $4{ }^{\circ} \mathrm{C}$ in lysis buffer $(0.5 \%$ sodium deoxycholate, $1 \%$ Nonidet P40, $0.1 \%$ sodium dodecyl sulfate, 100 $\mu \mathrm{g} / \mathrm{mL}$ phenylmethylsulphonyl fluoride, $1 \mathrm{mmol} / \mathrm{L}$ sodium orthovanadate, and protease inhibitor cocktail). Human skin samples were treated with $4 \mathrm{mg} / \mathrm{mL}$ dispase (Gibco/ Invitrogen) for 1 hour at $37^{\circ} \mathrm{C}$, and the epidermis was peeled from the dermis. Protein $(30 \mu \mathrm{g})$ was separated on SDSpolyacrylamide gels and transferred onto polyvinylidine fluoride membranes (Bio-Rad, Hercules, CA). Nonspecific protein binding was blocked by incubating the membranes in $5 \% \mathrm{w} / \mathrm{v}$ nonfat milk powder in TBS-T. The membranes were incubated with mouse anti-IL-1 $\beta$ antibody MAB201 (R\&D Systems, Minneapolis MN) diluted 1:1000, sheep anti-11 $\beta$ HSD1 antibody diluted 1:200 (The Binding Site, Birmingham, UK), or mouse anti- $\beta$-actin antibody A5441 (SigmaAldrich) diluted 1:10,000 for 60 minutes at room temperature. Then, the membranes were washed three times in TBS$\mathrm{T}$ for 5 minutes. Finally, the membranes were incubated with horseradish peroxidase-conjugated anti-mouse or anti-sheep antibody at a dilution of 1:10,000 for 60 minutes at room temperature. Protein bands were detected with the ECL Plus kit (GE Healthcare, Buckinghamshire, UK). The intensity of the bands was quantified with ImageJ software version 1.48V (NIH, Bethesda, MD; https://imagej.nih.gov/ ij/download.html).

\section{Enzyme-Linked Immunosorbent Assay}

Blood was collected from each mouse in the evening, and the plasma corticosterone concentration was measured with a corticosterone electroimmunoassay kit (Cayman Chemical Company, Ann Arbor, MI). For IL- $1 \alpha$, culture media was collected, and IL-1 $\alpha$ concentration was measured with an IL-1 $\alpha$ mouse enzyme-linked immunosorbent assay kit (R\&D Systems). For organ culture analysis, full-thickness skin harvested from 12-week-old mouse ear was treated with $4 \mathrm{mg} / \mathrm{mL}$ dispase (Gibco/Invitrogen) for 1 hour at $37^{\circ} \mathrm{C}$, and the epidermis was peeled from the dermis. The epidermis $\left(25 \mathrm{~cm}^{2}\right)$ was cultured in cortisol- and phenol redfree EpiLife for 24 hours with or without $1 \mathrm{nmol} / \mathrm{L} 11 \mathrm{DHC}$, followed by harvesting of culture medium.

\section{Statistical Analysis}

The data are expressed as means $\pm \mathrm{SD}$. The Student's $t$-test was used to determine the level of significance of differences between the two groups. Analysis of variance for the groups was performed by analysis of variance followed by the Bonferroni-Dunn for multiple comparisons to allow 
A
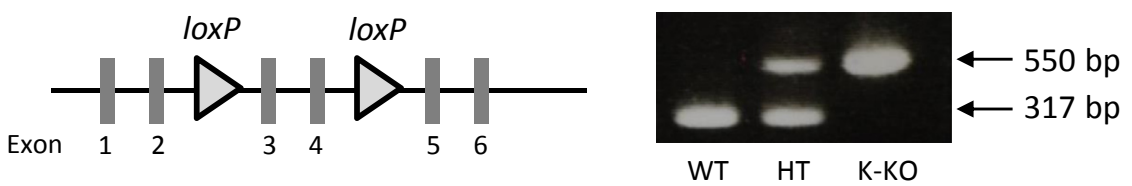

B

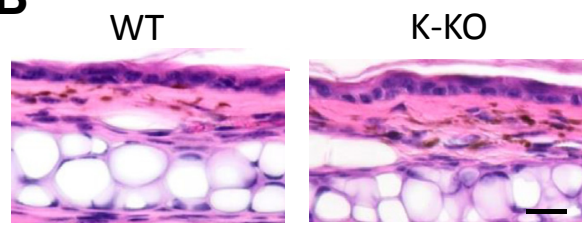

C

Keratinocytes

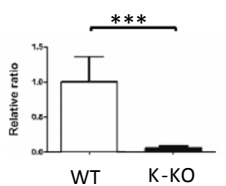

Liver
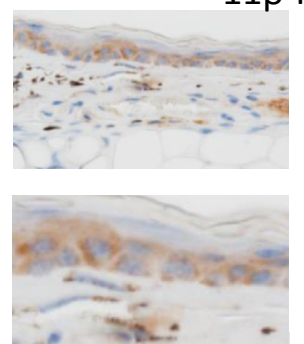

Rabbit IgG

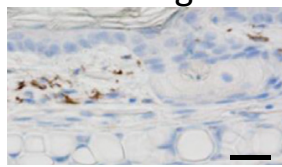

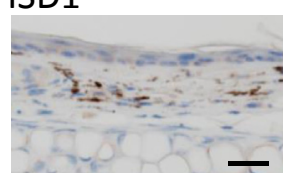

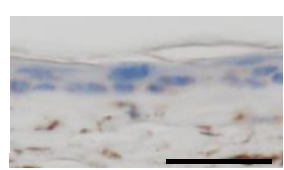

-

D

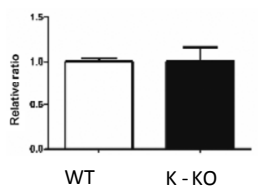

D

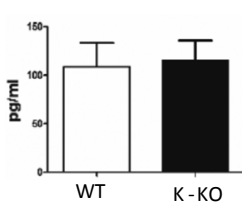

E

Adrenal gland

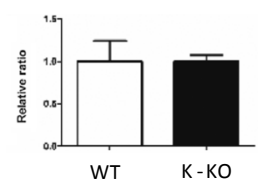

WT K-KO

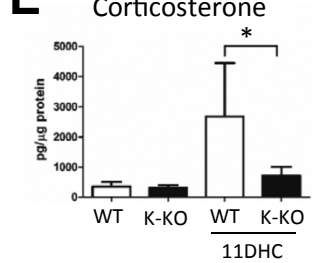

F
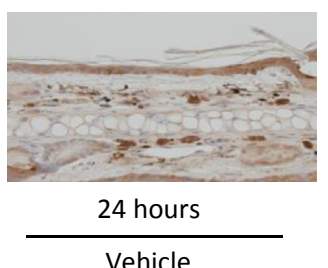

Vehicle

G

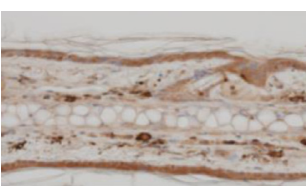

24 hours

Vehicle

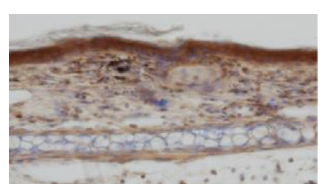

24 hours

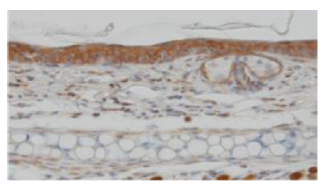

48 hours

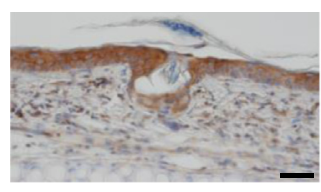

72 hours

OXA $0.2 \%$ (CHS)

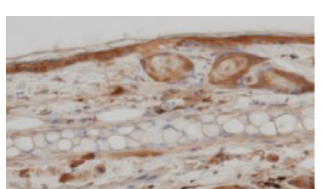

24 hours

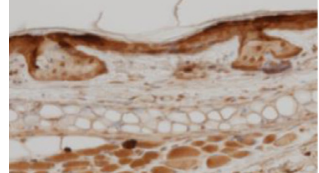

48 hours

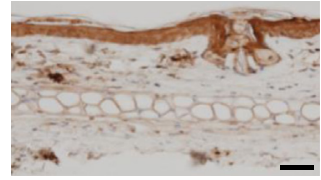

72 hours

OXA $0.2 \%$ (irritant dermatitis)

Figure 1 Generation of K5-Hsd11b1-KO mice. A: Construction of Hsd11b1 $1^{\text {tm } 1 a /+}$ ES cells (left). Genotyping of mice shows WT band at 317 bp and K-K0 band at 550 bp. B: Hematoxylin and eosin staining (upper panel) and immunohistochemical staining of 11ß-HSD1 (lower panel) of 8-week-old WT and K5Hsd11b1-KO mouse ear skin. Rabbit IgG was used as an isotype control. C: Quantitative real-time PCR analysis of relative expression of 11ß-HSD1 in keratinocytes, adrenal gland, and liver of WT and K-KO mice. HPRT was used as an internal control. D: ELISA analysis of serum corticosterone concentration of WT and K-KO mice. E: ELISA of corticosterone concentration in organ cultures of epidermis derived from WT and K-KO mice treated with or without 1

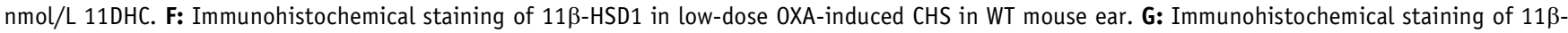
HSD1 in low-dose OXA-induced irritant dermatitis model in WT mouse ear. Data are expressed as means \pm SD. $n=4$ to $6 .{ }^{*} P<0.05$, based on one-way analysis of variance, followed by the Bonferroni-Dunn test for multiple comparisons; ${ }^{* * *} P<0.001$, based on Student's $t$-test. Scale bar $=25 \mu \mathrm{m}$. CHS, contact hypersensitivity; DNFB, 2,4-dinitrofluorobenzene; ELISA, enzyme-linked immunosorbent assay; ES, embryonic stem; HPRT, hypoxanthine phosphoribosyltransferase; HT, heterozygous knock out; K-KO, homozygous knockout; 0XA, oxazolone; WT, wild-type; 11DHC, 11-dehydrocorticosterone; 11ßHSD1, 11ß-hydroxysteroid dehydrogenase 1. 
pairwise testing for significant differences between groups. Statistical significance was defined as $P<0.05$.

\section{Results}

\section{Generation of K5-Hsd11b1-KO Mice}

To investigate the function of $11 \beta$-HSD1 in keratinocytes, we generated $K 5-H s d 11 b 1-K O$ mice. A conditional $H s d 11 b 1$ allele was generated by flanking exons 3 (ENSMUSE00001341737) and 4 (ENSMUSE00001337115) with loxP sites (Figure 1A). Expression of $11 \beta$-HSD1 was significantly decreased in $K 5-H s d 11 b 1-K O$ keratinocytes (Figure 1B). However, K5-Hsd11b1-KO mouse skin at steady state did not show a significant skin phenotype macroscopically or microscopically (Figure 1B). Expression of $11 \beta$-HSD1 was decreased in keratinocytes but not in adrenal gland or liver, indicating targeted $\mathrm{KO}$ in keratinocytes (Figure 1C). Serum corticosterone concentration did not differ in wild-type and K5-Hsd11b1-KO mice (Figure 1D), which is in contrast to the findings of our previous study in $H s d 11 b^{-1-}$ mice. ${ }^{35}$ Corticosterone concentration in organ cultures of epidermis derived from $\mathrm{K} 5-\mathrm{Hs}$ d1 1bl-KO mice was significantly lower than in those from wild-type mice treated with 11DHC (Figure 1E).

\section{Expression of $11 \beta$-HSD1 Increases in Low-Dose} OXA-Induced CHS and Irritant Dermatitis in Mouse Skin

To examine the dynamics of $11 \beta-H S D 1$ expression after contact hypersensitivity (CHS) and irritant dermatitis, wildtype mice were sensitized with 5\% OXA and elicited with $0.2 \%$ OXA to the ear (CHS model) or treated with single application of $0.2 \%$ OXA to the ear (irritant dermatitis model). Expression of $11 \beta-H S D 1$ in epidermis increased after exposure to $0.2 \%$ OXA in both the CHS and irritant dermatitis models (Figure 1, F and G).

\section{Low-Dose OXA-Induced Irritant Dermatitis Is Exacerbated in K5-Hsd11b1-KO Mice}

To determine the role of $11 \beta$-HSD1 in hapten-induced irritant dermatitis, ear swelling induced by a single application of OXA was evaluated. Ear swelling induced by low-dose $(0.2 \%)$ OXA was significantly greater in $\mathrm{K} 5-\mathrm{Hs}$ sl1 lbl-KO than in wild-type mice (Figure 2A). Accordingly, IL-1 $\beta$ expression was significantly elevated after 24,72 , and 168 hours in ears with $0.2 \%$ OXA-induced irritant dermatitis in $\mathrm{K} 5$-Hsd11b1-KO mice compared with wild-type mice (Figure 2, B-D). CXCL1 expression trended to increase after
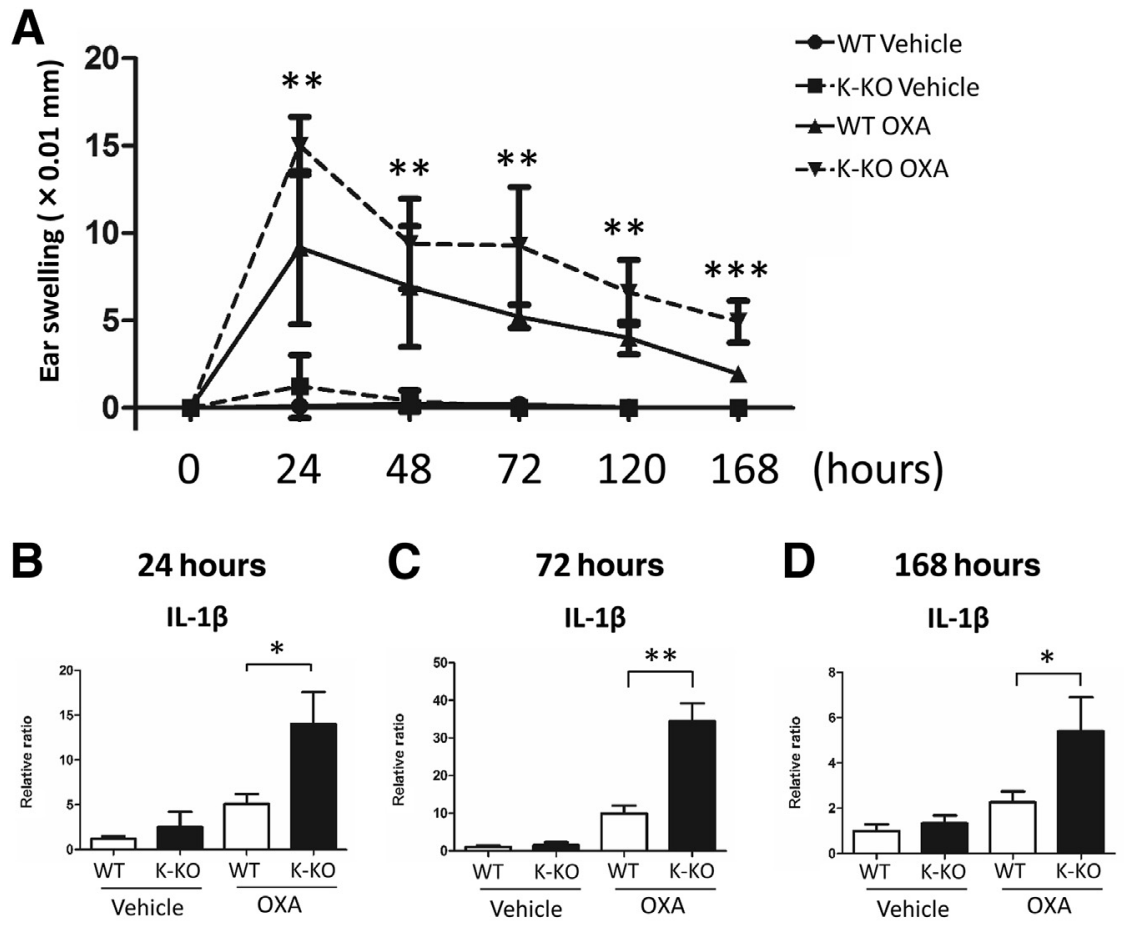

CXCL1
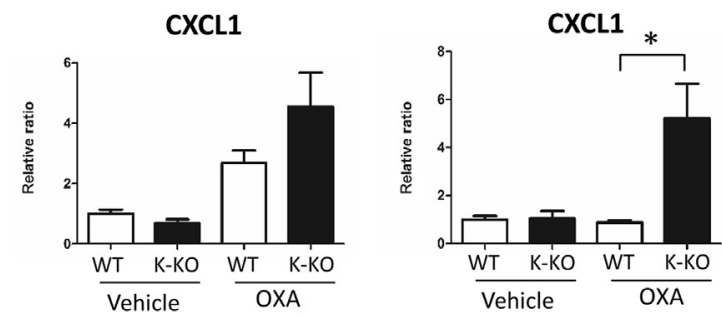

Figure 2 Low-dose OXA-induced irritant dermatitis is exacerbated in $K 5-H s d 11 b 1-K O$ mice. A: Ear swelling in models of irritant dermatitis induced by $0.2 \%$ OXA. B-D: Quantitative real-time PCR analysis of relative expression of IL-1 $\beta$ and CXCL1 in vehicle-treated and $0.2 \% 0 X A$-induced irritant dermatitis in skin of WT and K-KO mice at 24 (B), 72 (C), and 168 (D) hours. HPRT was used as an internal control. Data are expressed as means \pm SD. $n=6 .{ }^{*} P<0.05,{ }^{*} P P<0.01$, and $* * * P<0.001$, based on one-way analysis of variance, followed by the Bonferroni-Dunn test for multiple comparisons. HPRT, hypoxanthine phosphoribosyltransferase; K-KO, homozygous knockout; OXA, oxazolone; WT, wild-type. 
A

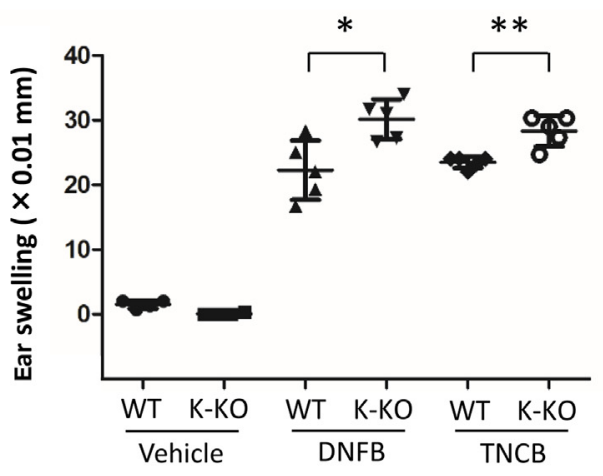

B

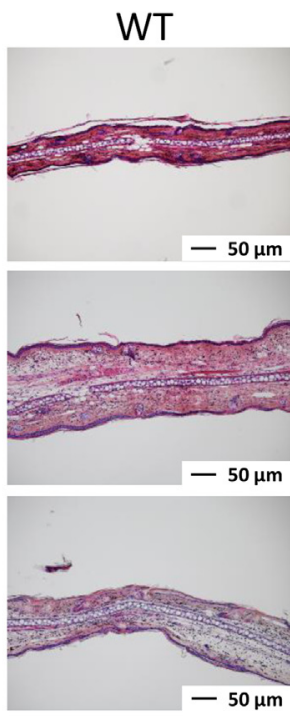

D
$\mathrm{F} 4 / 80$

WT

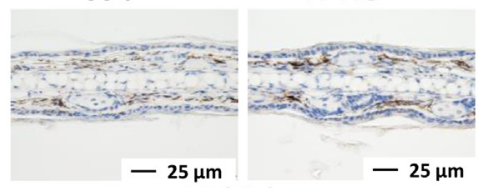

Vehicle

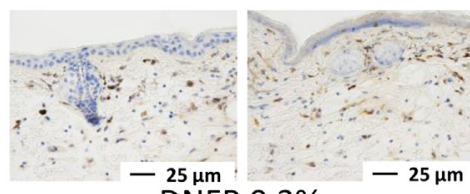

DNFB 0.3\%

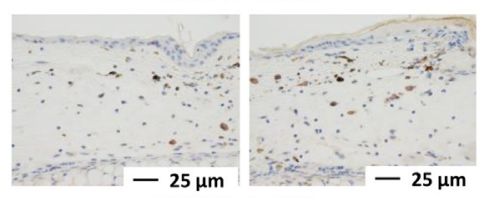

TNCB $0.2 \%$
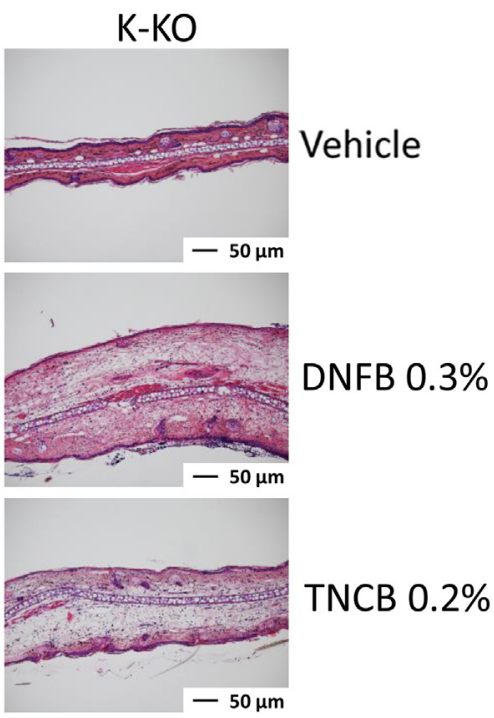

E Gr-1
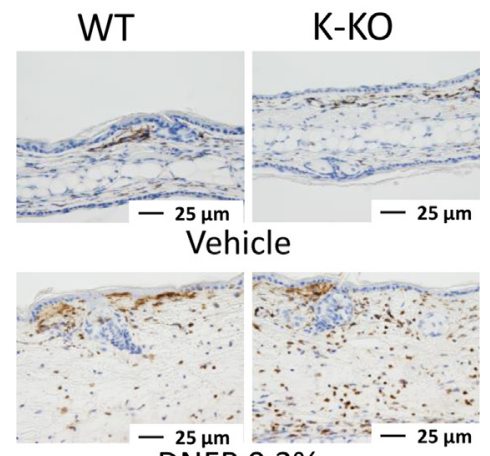

DNFB $0.3 \%$

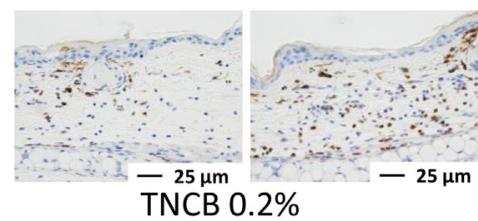

TNCB $0.2 \%$

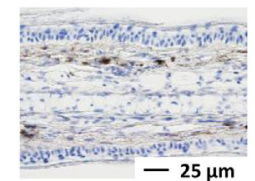

Rat $\lg G$
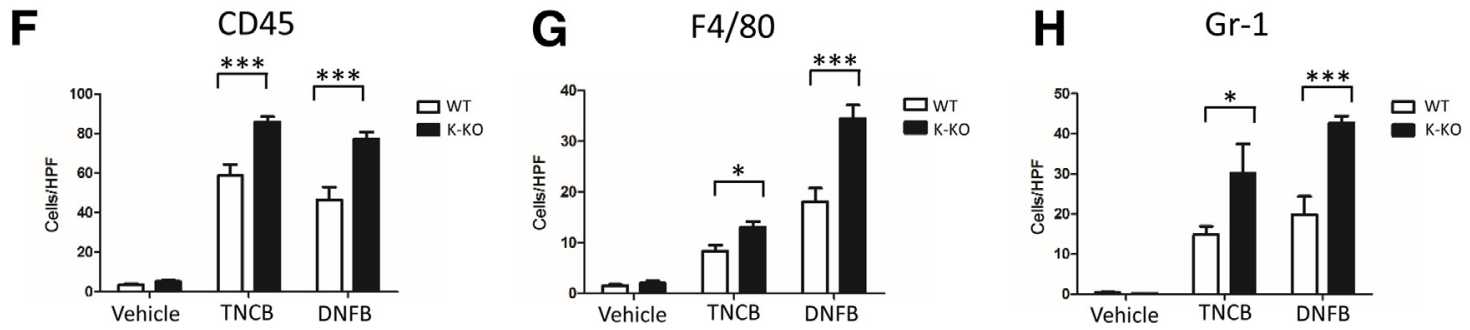

Figure 3 Low-dose DNFB- and TNCB-induced irritant dermatitis is exacerbated in K5-Hsd11b1-KO mice. A: Ear swelling in vehicle-treated mice and in 0.3\% DNFB- and 0.2\% TNCB-induced models of irritant dermatitis (24 hours). B: Hematoxylin and eosin staining of ear skin of vehicle-treated mice and in models of $0.3 \%$ DNFB- and $0.2 \%$ TNCB-induced irritant dermatitis (30 hours). C-E: Representative DAB staining of CD45, F4/80, and Gr-1. Rat IgG was used as isotype control. $\mathbf{F}-\mathrm{H}$ : The number of $\mathrm{CD}_{4} 5^{+}, \mathrm{F} 4 / 80^{+}$, and $\mathrm{Gr}-1^{+}$cells per high-power field. Three sections from each mouse were evaluated. Data are expressed as means \pm SD. $n=6$. ${ }^{*} P<0.05,{ }^{*} P<<0.01$, based on one-way analysis of variance, followed by the Bonferroni-Dunn test for multiple comparisons (A); ${ }^{*} P<0.05,{ }^{* *} P<0.001$, based on two-way analysis of variance, followed by the Bonferroni-Dunn test for multiple comparisons (F-H). DAB, diaminobenzidine; DNFB, 2,4-dinitrofluorobenzene; K-K0, homozygous knockout; TNCB, 2,4,6-trinitro-1-chlorobenzene; WT, wild-type. 

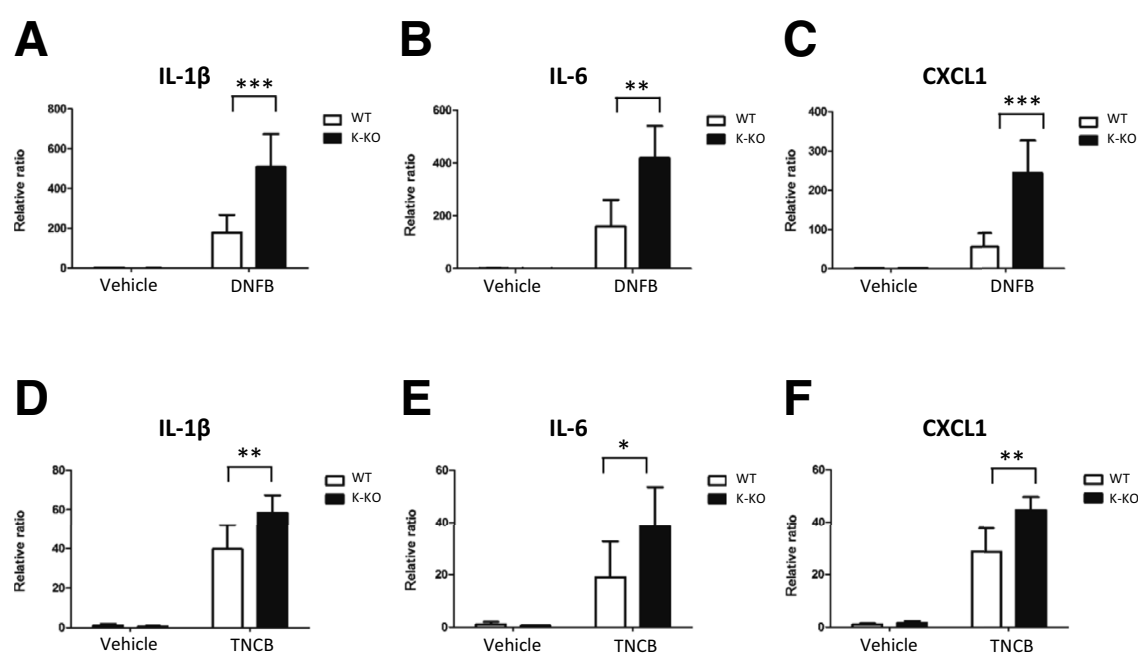

E
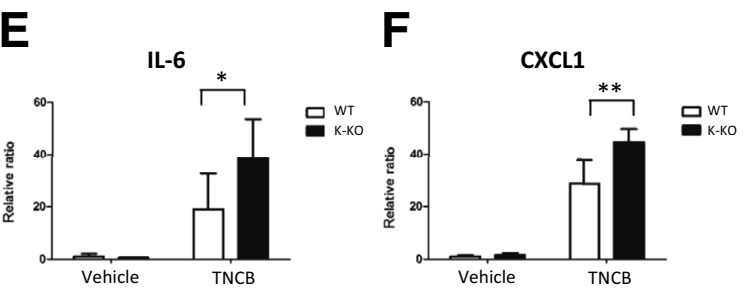

G

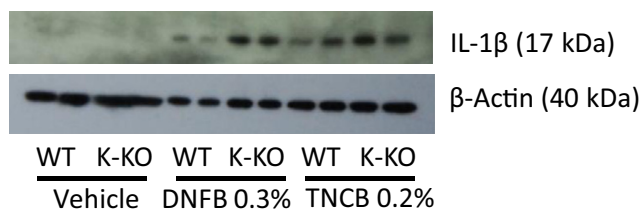

Figure 4 Low-dose DNFB- and TNCB-induced irritant proinflammatory cytokine expression is exacerbated in K5-Hsd11b1-KO mice. A-F: Quantitative real-time $P C R$ analysis of relative expression of IL-1 $\beta$ (A and $\mathbf{D}$ ), IL-6 (B and $\mathbf{E}$ ), and CXCL1 $(\mathbf{C}$ and $\mathbf{F})$ in $0.3 \%$ DNFB-induced $(\mathbf{A}-\mathbf{C})$ and $0.2 \%$ TNCB-induced (D-F) irritant dermatitis (30 hours) in WT and K-KO mouse skin. HPRT was used as an internal control. G: Western blot analysis of IL-1 $\beta$ expression in ear skin of $0.3 \%$ DNFB- and $0.2 \%$ TNCB-induced irritant dermatitis (30 hours). $\beta$ Actin was used as an internal control. Data are expressed as means \pm SD. $n=6$. ${ }^{*} P<0.05$, ${ }^{* *} P<0.01$, and ${ }^{* * *} P<0.001$, based on one-way analysis of variance, followed by the BonferroniDunn test for multiple comparisons. DNFB, 2,4-dinitrofluorobenzene; HPRT, hypoxanthine phosphoribosyltransferase; K-K0, homozygous knockout; TNCB, 2,4,6-trinitro-1-chlorobenzene; WT, wild-type.
24 and 168 hours and was significantly elevated after 72 hours in ears with $0.2 \%$ OXA-induced dermatitis in K5-Hsd11b1-KO mice compared with wild-type mice.

\section{Low-Dose DNFB- and TNCB-Induced Irritant Dermatitis Is Exacerbated in $\mathrm{K} 5$-Hsd11b1-KO Mice}

We further evaluated irritant dermatitis induced by the haptens DNFB and TNCB in K5-Hsdl1b1-KO mice. As in OXA-induced irritant dermatitis, a single application of $0.3 \%$ DNFB or $0.2 \%$ TNCB to the mouse ear significantly enhanced ear swelling in K5-Hsd11b1-KO mice compared with wild-type mice (Figure 3A). Hematoxylin and eosin staining found enhanced edema with an increase in infiltrating cells in K5-Hsd11b1-KO mice (Figure 3B). Accordingly, the number of infiltrating leukocytes $\left(\mathrm{CD} 45^{+}\right.$cells) (Figure 3, C and F), macrophages (F4/80 $0^{+}$cells) (Figure 3, D and $\mathrm{G}$ ), and neutrophils (Gr- $1^{+}$cells) (Figure $3, \mathrm{E}$ and $\mathrm{H}$ ) was significantly higher in both DNFB- and TNCB-induced irritant dermatitis in $\mathrm{K} 5$-Hsdllbl-KO mice. No apparent difference was observed in expression of glucocorticoid receptor in the wild-type and K5-Hsd11b1-KO mice (Supplemental Figure S1). Next, expression of the proinflammatory cytokines IL-1 $\beta$, IL-6, and CXCL1 in harvested full-thickness skin was evaluated. Expression of all three cytokines was significantly elevated in $\mathrm{K} 5-\mathrm{Hs} d 1 \mathrm{lbl}-\mathrm{KO}$ mice compared with wild-type mice in both DNFB-induced irritant dermatitis (Figure 4, A-C) and TNCB-induced irritant dermatitis (Figure 4, D-F). In addition, increased IL-1 $\beta$ expression was also found by Western blot analysis (relative intensity of IL-1 $\beta / \beta$-actin bands) (Figure $4 \mathrm{G}$ ).
Topical Corticosterone Application Dose Dependently Suppresses TNCB-Induced Irritant Dermatitis

Because the data suggest that the activation of corticosterone by $11 \beta-H S D 1$ in keratinocytes suppressed hapten-induced dermatitis, we next evaluated the effect of topical corticosterone application in the model of TNCB-induced irritant dermatitis. Corticosterone at doses of $10^{-2}$ to $10^{-4} \mathrm{~mol} / \mathrm{L}$ was topically applied after application of $0.2 \%$ TNCB to the mouse ear. Topical application of corticosterone suppressed TNCB-induced ear swelling in a dose-dependent manner (Figure 5A). Consistent with this observation, IL-1 $\beta$, and CXCL1 expression was also dose dependently suppressed by topical corticosterone application (Figure 5, B-D).

\section{Corticosterone Dose Dependently Suppresses}

TNBS-Induced Inflammation in Keratinocytes in Culture

Keratinocytes play an important role in hapten-induced dermatitis by producing cytokines, such as IL-1 $\beta$, IL- $1 \alpha$, tumor necrosis factor- $\alpha$, and IL-18, with hapten stimulation. ${ }^{38,39}$ We next evaluated the effect of corticosterone at various doses in vitro with the use of mouse keratinocytes. TNBS was used in the in vitro study because it is water soluble. Addition of TNBS to the medium dose dependently induced the expression of $11 \beta-H S D 1, \mathrm{IL}-1 \alpha$, and IL-1 $\beta$ (Figure 5, E-G). Corticosterone at a physiologic dose of $10^{-10}$ to $10^{-6} \mathrm{~mol} / \mathrm{L}$ was added to culture medium after stimulation of cells with TNBS. TNBS-induced IL- $1 \alpha$ mRNA expression was significantly suppressed by $10^{-6} \mathrm{~mol} / \mathrm{L}$ corticosterone (Figure $5 \mathrm{H}$ ), and TNBS-induced IL-1 $\beta$ mRNA 

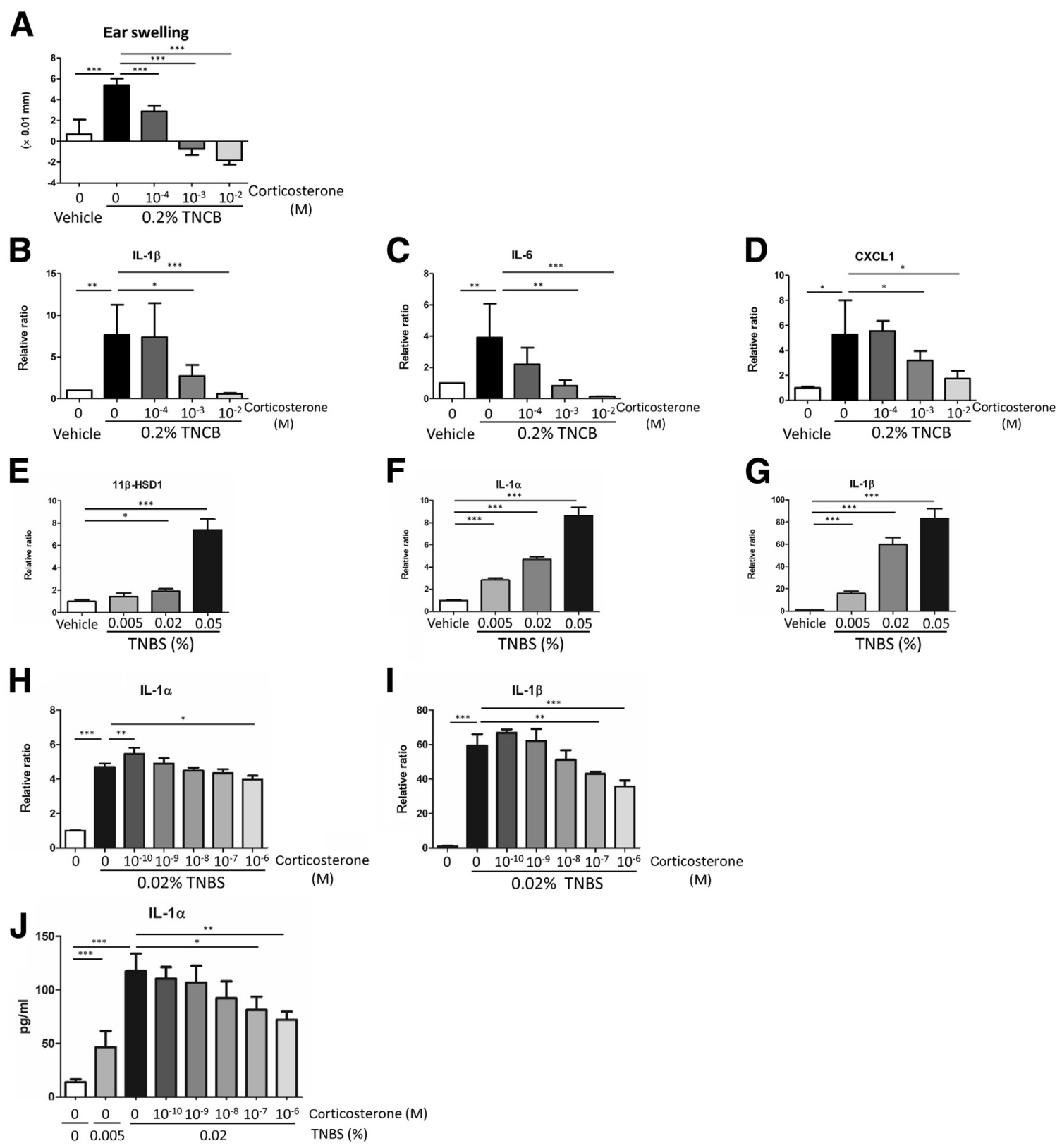

Figure 5 Topical cortisol application dose dependently suppresses TNCB-induced irritant dermatitis in vivo and TNCB-induced inflammation in keratinocytes in vitro. A: Ear swelling in mice treated with vehicle and TNCB with or without indicated dose of corticosterone (24 hours). B-D: qPCR analysis of relative expression of IL-1B (B), IL-6 (C), and CXCL1 (D) in mouse ear skin treated with vehicle and $0.2 \%$ TNCB with or without indicated dose of corticosterone (30 hours). HPRT was used as an internal control. E-G: qPCR analysis of relative expression of $11 \beta-H S D 1(\mathbf{E}), \mathrm{IL}-1 \alpha(\mathbf{F})$, and IL-1 $1 \beta(\mathbf{G})$ in cultured mouse keratinocytes treated with vehicle or indicated doses of TNBS for 24 hours. HPRT was used as an internal control. $\mathbf{H}$ and $\mathbf{I}$ : qPCR analysis of relative expression of IL-1 $\alpha(\mathbf{H})$ and IL-1 $\beta$ (I) in cultured WT mouse keratinocytes treated with vehicle or TNBS with or without indicated dose of cortisol for 24 hours. HPRT was used as an internal control. J: Enzyme-linked immunosorbent assay analysis of IL-1 $\alpha$ in medium of cultured WT mouse keratinocytes treated with vehicle and TNBS with or without the indicated dose of cortisol for 24 hours. Data are expressed as means \pm SD. $n=6(\mathbf{B}-\mathbf{D}) ; n=4(\mathbf{E}-\mathbf{I}) .{ }^{*} P<0.05,{ }^{*} P<0.01$, and ${ }^{* * *} P<0.001$, based on oneway analysis of variance, followed by the Bonferroni-Dunn test for multiple comparisons. HPRT, hypoxanthine phosphoribosyltransferase; qPRC, quantitative realtime PCR; TNBS, 2,4,6-trinitrobenzenesulfonic acid; TNCB, 2,4,6-trinitro-1-chlorobenzene; WT, wild-type; 11ß-HSD1, 11ß-hydroxysteroid dehydrogenase 1.

expression was significantly suppressed by $10^{-7}$ and $10^{-6}$ $\mathrm{mol} / \mathrm{L}$ corticosterone (Figure $5 \mathrm{I}$ ). In addition, the results of the enzyme-linked immunosorbent assay found that TNBSinduced IL- $1 \alpha$ production was significantly suppressed by $10^{-7}$ and $10^{-6} \mathrm{~mol} / \mathrm{L}$ corticosterone (Figure 5J). TNBSinduced IL-1 $\beta$ was undetectable in culture medium (data not shown).

\section{Response to 11DHC Application in TNCB-Induced Irritant Dermatitis Is Attenuated in K5-Hsd11b1-KO Mice}

Finally, we evaluated the effect of topical application of 11DHC in TNCB-induced irritant dermatitis. Suppression of TNCBinduced ear swelling was milder in the 11DHC group than in the corticosterone group of $\mathrm{K5}-\mathrm{Hs} d \mathrm{ll} \mathrm{lbl}$ - $\mathrm{KO}$ mice (Figure 6A). 

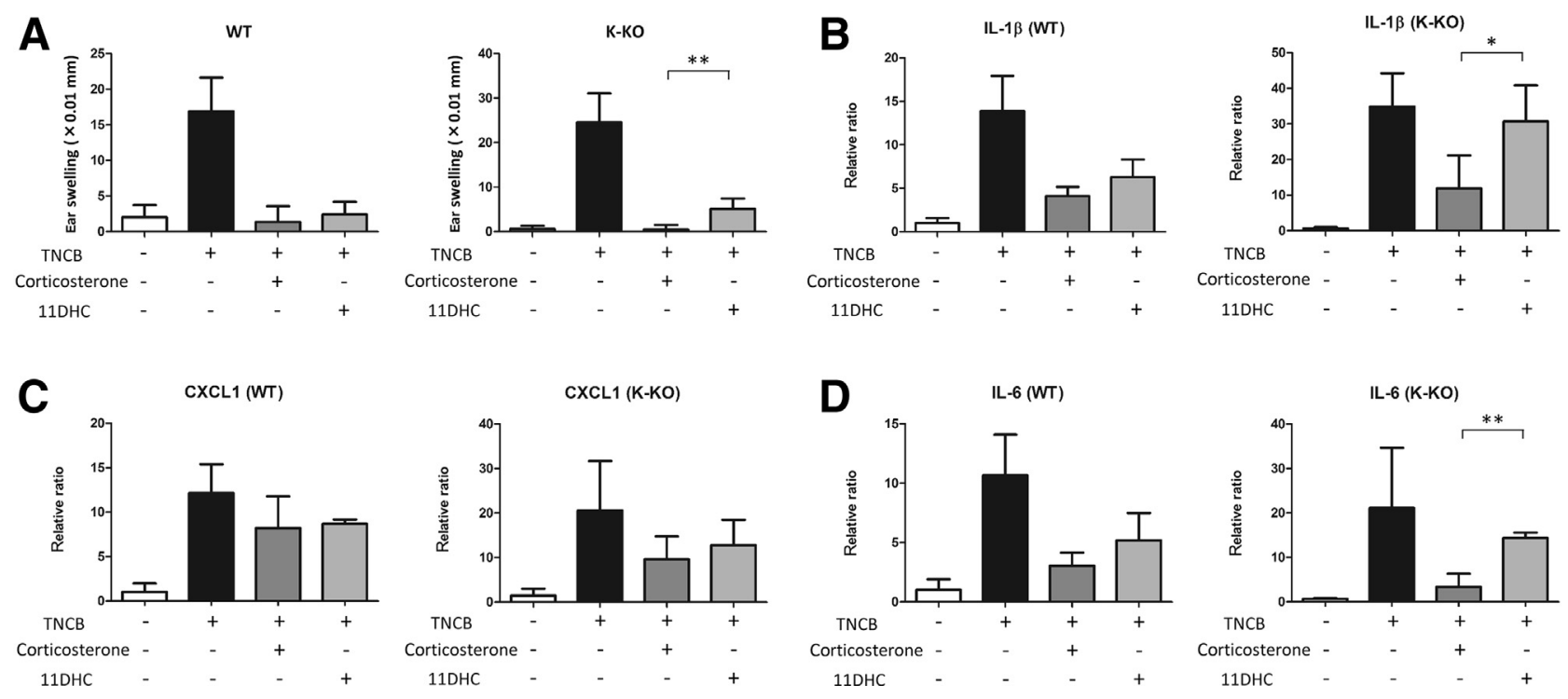

Figure 6 Response to 11DHC application in TNCB-induced irritant dermatitis is attenuated in K5-Hsd11b1-KO mice. A and B: Ear swelling in mice treated with $0.2 \%$ TNCB with or without $10^{-3} \mathrm{~mol} / \mathrm{L}$ corticosterone or $10^{-3} \mathrm{~mol} / \mathrm{L} 11 \mathrm{DHC}$ for 24 hours. B-D: Quantitative real-time PCR analysis of relative expression of IL$1 \beta(B), C X C L 1(C)$, and IL-6 (D) in mouse ear skin treated with $0.2 \%$ TNCB with or without $10^{-3} \mathrm{~mol} / \mathrm{L}$ corticosterone or $10^{-3} \mathrm{~mol} / \mathrm{L} 11 \mathrm{DHC}$ for 26 hours. HPRT was used as an internal control. Data are expressed as means \pm SD. $n=6 .{ }^{*} P<0.05,{ }^{*} P<0.01$, based on one-way analysis of variance, followed by the BonferroniDunn test for multiple comparisons. HPRT, hypoxanthine phosphoribosyltransferase; K-KO, homozygous knockout; TNCB, 2,4,6-trinitro-1-chlorobenzene; WT, wild-

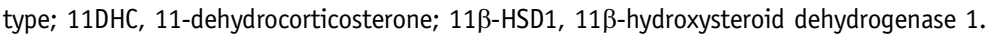

Consistent with this observation, IL-1 $\beta$ and IL-6 expression was also only mildly suppressed by $11 \mathrm{DHC}$ compared with corticosterone in $\mathrm{K5}-\mathrm{Hsd1}$ lbl-KO mice (Figure 6, B-D).

\section{Expression of $11 \beta$-HSD1 Decreases in Psoriasis Vulgaris Epidermis}

We previously reported decreased expression of $11 \beta$-HSD1 in skin tumors, such as basal cell carcinoma and squamous cell carcinoma and in seborrheic keratosis, and the association of 11 $\beta$-HSD1 expression level with cell proliferation. ${ }^{32}$ The expression of $11 \beta$-HSD1 was also decreased in epidermis in psoriasis vulgaris skin (Figure 7, A-C). In addition, 11 $\beta$-HSD1 expression was lower in lesional psoriasis vulgaris skin than in marginal skin (Figure 7D). The $11 \beta$-HSD1 staining score was significantly lower in psoriasis vulgaris than in healthy skin and correlated negatively with epidermal thickness in psoriasis vulgaris (Figure 7E). Expression of 11 $\beta$-HSD1 was also significantly decreased by Western blot analysis in epidermis in psoriasis vulgaris (Figure 7, F and G).

\section{Discussion}

Skin is exposed daily to various forms of mechanical and chemical stimulation. We hypothesized that a local stressregulatory mechanism might exist in keratinocytes to counterbalance this repeated stimulation. To address this, we focused on local corticosterone activation by $11 \beta$-HSD1 in keratinocytes. In this study, we found that low-dose
OXA-induced irritant dermatitis was exacerbated in K5-Hsd11b1-KO mice. K5-Hsd11b1-KO mice also showed an enhanced inflammatory reaction to single applications of low-dose TNCB and DNFB. These results suggest that irritant dermatitis induced by haptens is exacerbated in K5-Hsd11b1-KO mice, probably through absence of corticosterone activation by $11 \beta$-HSD1 in keratinocytes. Because topical cortisol application dose dependently suppressed TNCB-induced irritant dermatitis, and because suppression of TNCB-induced irritant dermatitis was attenuated in K5-Hsd11b1-KO mice treated with 11DHC compared with $11 \mathrm{DHC}$-treated wild-type mice, local cortisol activation is likely important to suppress skin inflammation.

Keratinocytes play an important role in CHS, as do immune cells, such as $\mathrm{T}$ cells and dendritic cells. Haptens directly stimulate keratinocytes to produce proinflammatory cytokines, such as IL-1 $\beta$, IL-18, and tumor necrosis factor$\alpha .{ }^{38}$ Neutrophil-recruiting chemokines, such as CXCL1 and CXCL2, are also produced by activated keratinocytes. ${ }^{39}$ In addition, IFN- $\gamma$ and tumor necrosis factor- $\alpha$ produced by recruited $\mathrm{T}$ helper type 1 cells in CHS stimulate keratinocytes to produce chemokines, such as chemokine ligand 8 , CXCL9, CXCL10, and CXCL11. ${ }^{40}$ In our study, the addition of TNBS to culture medium dose dependently induced IL- $1 \alpha$ and IL- $1 \beta$ production, suggesting the importance of these cytokines in keratinocytes in hapten-induced dermatitis. IL-1 $\beta$ was not detected in culture medium of cells treated with TNBS, possibly because activation of caspase-1 through inflammasome activation is essential to process IL$1 \beta$ in keratinocytes, and TNBS does not activate this mechanism. ${ }^{38}$ 

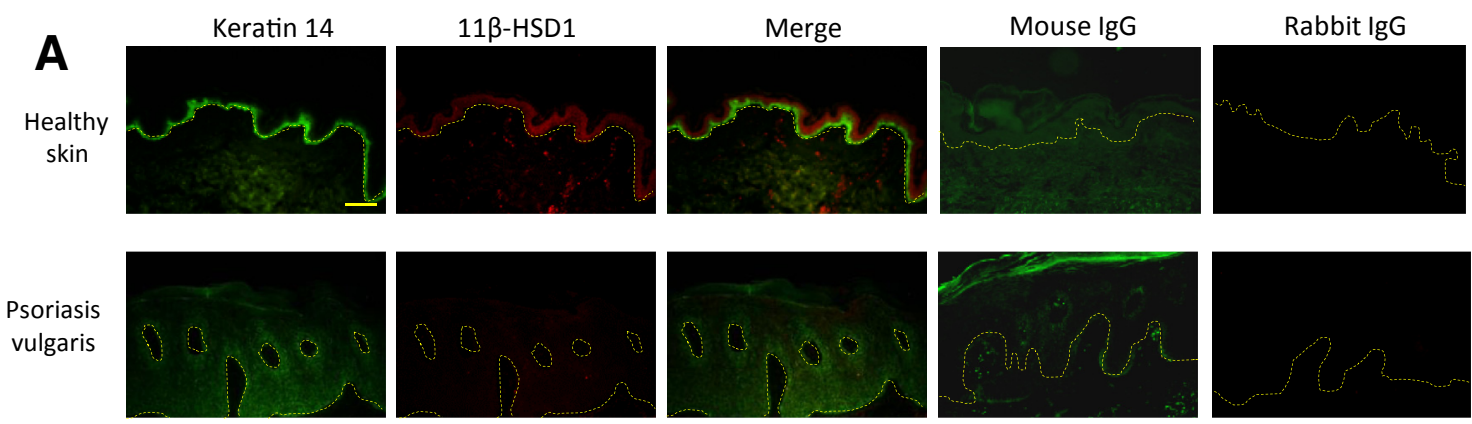

B
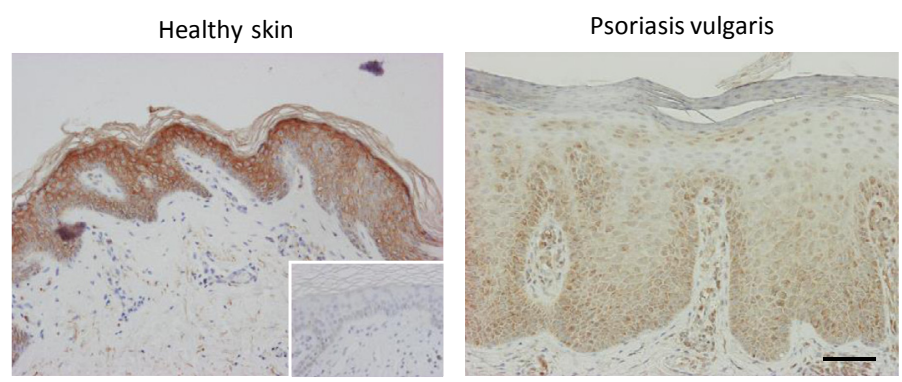

Psoriasis vulgaris

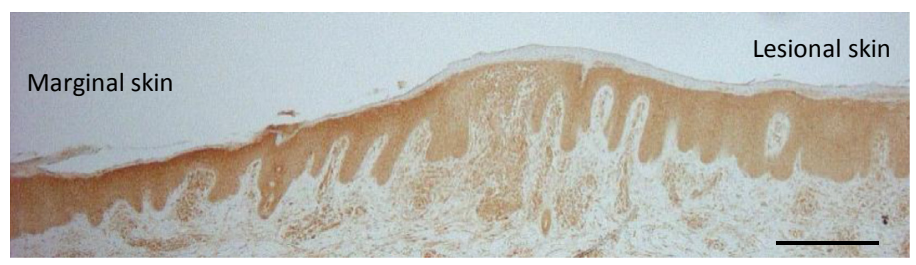

$\mathbf{F}$

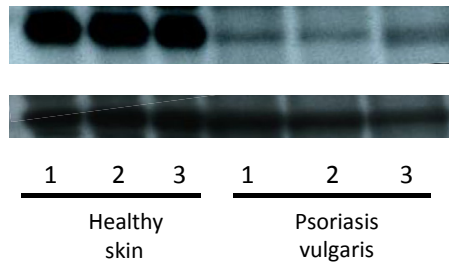

$11 \beta-H S D 1(32 \mathrm{kDa})$

$\beta$-actin (40 kDa)
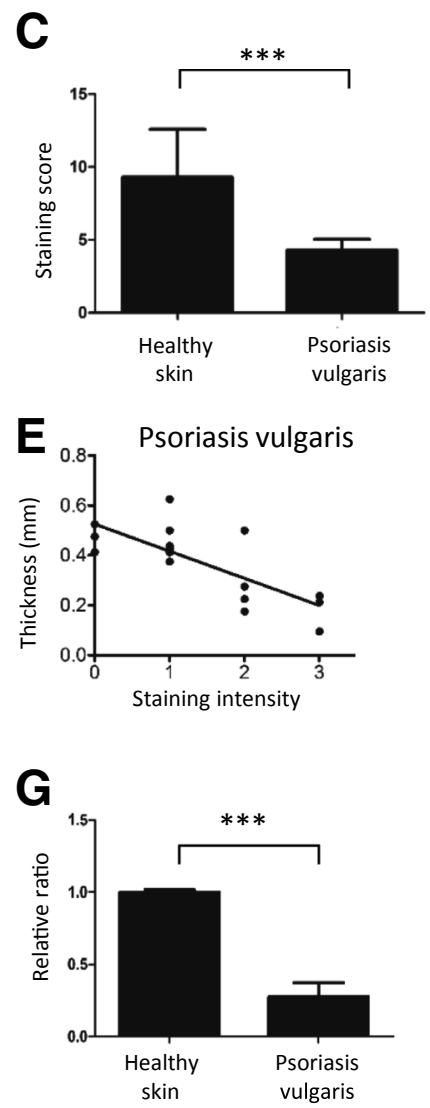

Figure 7 11ß-HSD1 expression decreases in psoriasis vulgaris epidermis. A: Representative immunofluorescence staining of $11 \beta-H S D 1$ (red) and keratin 14 (green) in healthy and psoriasis vulgaris skin. Rabbit and mouse IgG were used as isotype controls for $11 \beta$-HSD1 and keratin 14, respectively. B: Representative DAB staining of $11 \beta-H S D 1$ in psoriasis vulgaris. C: $11 \beta$-HSD1 staining score in healthy and psoriasis vulgaris skin. D: DAB staining of $11 \beta-H S D 1$ in psoriasis vulgaris, including marginal skin and lesional skin. E: Correlation between epidermal thickness and 11ß-HSD1 staining score in psoriasis vulgaris. F: Western blot analysis of $11 \beta$-HSD1 expression in healthy and psoriasis vulgaris skin. $\beta$-Actin was used as an internal control. G: Intensity of $11 \beta$-HSD1 band relative to that of $\beta$-actin. Data are expressed as means \pm SD. $n=19$ healthy skin samples; $n=15$ psoriasis vulgaris skin

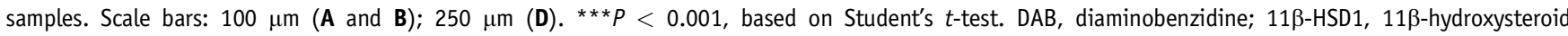
dehydrogenase 1.

Although GCs are strong immunosuppressive drugs, the endogenous GC, cortisol, is immunomodulatory rather than immunosuppressive. The action of GCs is concentration dependent. ${ }^{41}$ In our study, addition of cortisol at $10^{-7}$ or $10^{-6} \mathrm{~mol} / \mathrm{L}$ suppressed the expression of IL- $1 \alpha$ and IL- $1 \beta$. In human keratinocytes, IL-1 $\beta$-induced IL- 6 production was stimulated by low-dose $\left(10^{-10} \mathrm{~mol} / \mathrm{L}\right)$ cortisol but suppressed with high-dose $\left(10^{-5} \mathrm{~mol} / \mathrm{L}\right)$ cortisol, ${ }^{42}$ similar to the current results. Because 11 $\beta$-HSD1 regulates cortisol concentration between these physiologic doses, $11 \beta$-HSD1 in keratinocytes may be an important molecule in suppressing irritant dermatitis induced by low-dose haptens in our study. Note that CHS and irritant dermatitis induced by high-dose haptens were apparently no different in wild-type and K5-Hsd11b1-KO mice (data not shown). These data suggest that a local immunosuppressive effect through the action of $11 \beta-H S D 1$ in keratinocytes is only limited to mild inflammation. Although the cortisol production pathway is 
reported to be a minor one in keratinocytes compared with those of other steroids, ${ }^{43}$ we believe it is important in skin inflammation.

Finally, we evaluated $11 \beta$-HSD1 expression in psoriasis vulgaris. Expression of $11 \beta-H S D 1$ was decreased and negatively correlated with epidermal thickness. Expression of $11 \beta$-HSD1 might be decreased in psoriasis vulgaris due to epidermal hyperproliferation, because the $11 \beta-\mathrm{HSD} 1$ expression level is negatively correlated with keratinocyte proliferation. ${ }^{16,32}$ Considering the results in $\mathrm{K} 5-\mathrm{Hs}$ d1 l bl$K O$ mice, reduced $11 \beta$-HSD1 expression in keratinocytes might attenuate the local immunosuppressive effect in these cells and result in a hyperinflammatory response.

On the basis of our findings, we propose that $11 \beta$-HSD1 in keratinocytes suppresses mild hapten-induced irritant dermatitis, possibly through reduction of IL- $1 \alpha$ and IL-1 $\beta$ production in these cells. This is the first study to show the importance of local corticosterone activation in keratinocytes in vivo in suppressing local skin inflammation. Targeting the local cortisol activation system in keratinocytes might be a novel pharmaceutical strategy in the future.

\section{Acknowledgment}

We thank Kenju Nishida, Eriko Nobuyoshi, and Yumiko Fujii for research assistance.

\section{Supplemental Data}

Supplemental material for this article can be found at http://dx.doi.org/10.1016/j.ajpath.2016.01.014.

\section{References}

1. Davies E, MacKenzie SM: Extra-adrenal production of corticosteroids. Clin Exp Pharmacol Physiol 2003, 30:437-445

2. Noti M, Corazza N, Mueller C, Berger B, Brunner T: TNF suppresses acute intestinal inflammation by inducing local glucocorticoid synthesis. J Exp Med 2010, 207:1057-1066

3. Coste A, Dubuquoy L, Barnouin R, Annicotte JS, Magnier B, Notti M, Corazza N, Antal MC, Metzger D, Desreumaux P, Brunner T, Auwerx J, Schoonjans K: LRH-1-mediated glucocorticoid synthesis in enterocytes protects against inflammatory bowel disease. Proc Natl Acad Sci U S A 2007, 104:13098-13103

4. Mueller M, Cima I, Noti M, Fuhrer A, Jakob S, Dubuquoy L, Schoonjans K, Brunner T: The nuclear receptor LRH-1 critically regulates extra-adrenal glucocorticoid synthesis in the intestine. J Exp Med 2006, 203:2057-2062

5. Young MJ, Clyne CD, Cole TJ, Funder JW: Cardiac steroidogenesis in the normal and failing heart. J Clin Endocrinol Metab 2001, 86: $5121-5126$

6. Kayes-Wandover KM, White PC: Steroidogenic enzyme gene expression in the human heart. J Clin Endocrinol Metab 2000, 85: $2519-2525$

7. Ohtani T, Mano T, Hikoso S, Sakata Y, Nishio M, Takeda Y, Otsu K, Miwa T, Masuyama T, Hori M, Yamamoto K: Cardiac steroidogenesis and glucocorticoid in the development of cardiac hypertrophy during the progression to heart failure. J Hypertens 2009, 27:1074-1083
8. Hostettler N, Bianchi P, Gennari-Moser C, Kassahn D, Schoonjans K, Corazza N, Brunner T: Local glucocorticoid production in the mouse lung is induced by immune cell stimulation. Allergy 2012, 67:227-234

9. Slominski A, Wortsman J, Tuckey RC, Paus R: Differential expression of HPA axis homolog in the skin. Mol Cell Endocrinol 2007, 265-266: $143-149$

10. Slominski A, Gomez-Sanchez CE, Foecking MF, Wortsman J: Metabolism of progesterone to DOC, corticosterone and 18OHDOC in cultured human melanoma cells. FEBS Lett 1999, 455:364-366

11. Slominski A, Zbytek B, Szczesniewski A, Semak I, Kaminski J, Sweatman T, Wortsman J: CRH stimulation of corticosteroids production in melanocytes is mediated by ACTH. Am J Physiol Endocrinol Metab 2005, 288:E701-E706

12. Skobowiat C, Dowdy JC, Sayre RM, Tuckey RC, Slominski A: Cutaneous hypothalamic-pituitary-adrenal axis homolog: regulation by ultraviolet radiation. Am J Physiol Endocrinol Metab 2011, 301: E484-E493

13. Hannen RF, Michael AE, Jaulim A, Bhogal R, Burrin JM, Philpott MP: Steroid synthesis by primary human keratinocytes; implications for skin disease. Biochem Biophys Res Commun 2011, 404:62-67

14. Cirillo N, Prime SS: Keratinocytes synthesize and activate cortisol: first characterisation of a novel epidermal glucocorticoid system. J Cell Biochem 2011, 112:1499-1505

15. Vukelic S, Stojadinovic O, Pastar I, Rabach M, Krzyzanowska A, Lebrun E, Davis SC, Resnik S, Brem H, Tomic-Canic M: Cortisol synthesis in epidermis is induced by IL-1 and tissue injury. J Biol Chem 2011, 286:10265-10275

16. Terao M, Murota H, Kimura A, Kato A, Ishikawa A, Igawa K, Miyoshi E, Katayama I: 11beta-Hydroxysteroid dehydrogenase-1 is a novel regulator of skin homeostasis and a candidate target for promoting tissue repair. PLoS One 2011, 6:e25039

17. Tiganescu A, Walker EA, Hardy RS, Mayes AE, Stewart PM: Localization, age- and site-dependent expression, and regulation of 11 beta-hydroxysteroid dehydrogenase type 1 in skin. J Invest Dermatol $2011,131: 30-36$

18. Slominski A, Wortsman J, Paus R, Elias PM, Tobin DJ, Feingold KR: Skin as an endocrine organ: implications for its function. Drug Discov Today Dis Mech 2008, 5:137-144

19. Slominski A, Zbytek B, Szczesniewski A, Wortsman J: Cultured human dermal fibroblasts do produce cortisol. J Invest Dermatol 2006, 126:1177-1178

20. Slominski A, Zjawiony J, Wortsman J, Semak I, Stewart J, Pisarchik A, Sweatman T, Marcos J, Dunbar C, C Tuckey R: A novel pathway for sequential transformation of 7-dehydrocholesterol and expression of the P450scc system in mammalian skin. Eur J Biochem 2004, 271:4178-4188

21. Slominski AT, Zmijewski MA, Skobowiat C, Zbytek B, Slominski RM, Steketee JD: Sensing the environment: regulation of local and global homeostasis by the skin's neuroendocrine system. Adv Anat Embryol Cell Biol 2012, 212:v, vii, 1-115

22. Slominski AT, Manna PR, Tuckey RC: Cutaneous glucocorticosteroidogenesis: securing local homeostasis and the skin integrity. Exp Dermatol 2014, 23:369-374

23. Slominski A, Ermak G, Mihm M: ACTH receptor, CYP11A1, CYP17 and CYP21A2 genes are expressed in skin. J Clin Endocrinol Metab 1996, 81:2746-2749

24. Seckl JR, Walker BR: Minireview: 11beta-hydroxysteroid dehydrogenase type 1- a tissue-specific amplifier of glucocorticoid action. Endocrinology 2001, 142:1371-1376

25. Sandeep TC, Walker BR: Pathophysiology of modulation of local glucocorticoid levels by 11 beta-hydroxysteroid dehydrogenases. Trends Endocrinol Metab 2001, 12:446-453

26. Odermatt A, Atanasov AG, Balazs Z, Schweizer RA, Nashev LG, Schuster D, Langer T: Why is 11beta-hydroxysteroid dehydrogenase type 1 facing the endoplasmic reticulum lumen? Physiological relevance of the membrane topology of 11 beta-HSD1. Mol Cell Endocrinol 2006, 248:15-23 
27. Masuzaki H, Paterson J, Shinyama H, Morton NM, Mullins JJ, Seckl JR, Flier JS: A transgenic model of visceral obesity and the metabolic syndrome. Science 2001, 294:2166-2170

28. Bryndova J, Zbankova S, Kment M, Pacha J: Colitis up-regulates local glucocorticoid activation and down-regulates inactivation in colonic tissue. Scand J Gastroenterol 2004, 39:549-553

29. Chapman KE, Coutinho AE, Zhang Z, Kipari T, Savill JS, Seckl JR: Changing glucocorticoid action: 11 beta-hydroxysteroid dehydrogenase type 1 in acute and chronic inflammation. J Steroid Biochem Mol Biol 2013, 137:82-92

30. Gambineri A, Fanelli F, Tomassoni F, Munarini A, Pagotto U, Andrew R, Walker BR, Pasquali R: Tissue-specific dysregulation of 11beta-hydroxysteroid dehydrogenase type 1 in overweight/obese women with polycystic ovary syndrome compared with weightmatched controls. Eur J Endocrinol 2014, 171:47-57

31. Ergang P, Leden P, Vagnerova K, Klusonova P, Miksik I, Jurcovicova J, Kment M, Pacha J: Local metabolism of glucocorticoids and its role in rat adjuvant arthritis. Mol Cell Endocrinol 2010, 323:155-160

32. Terao M, Itoi S, Murota H, Katayama I: Expression profiles of cortisolinactivating enzyme, 11beta-hydroxysteroid dehydrogenase-2, in human epidermal tumors and its role in keratinocyte proliferation. Exp Dermatol 2013, 22:98-101

33. Skobowiat C, Sayre RM, Dowdy JC, Slominski AT: Ultraviolet radiation regulates cortisol activity in a waveband-dependent manner in human skin ex vivo. Br J Dermatol 2013, 168:595-601

34. Tiganescu A, Tahrani AA, Morgan SA, Otranto M, Desmouliere A, Abrahams L, Hassan-Smith Z, Walker EA, Rabbitt EH, Cooper MS, Amrein K, Lavery GG, Stewart PM: 11beta-Hydroxysteroid dehydrogenase blockade prevents age-induced skin structure and function defects. J Clin Invest 2013, 123:3051-3060

35. Terao M, Tani M, Itoi S, Yoshimura T, Hamasaki T, Murota H, Katayama I: 11beta-hydroxysteroid dehydrogenase 1 specific inhibitor increased dermal collagen content and promotes fibroblast proliferation. PLoS One 2014, 9:e93051

36. Holmes MC, Kotelevtsev Y, Mullins JJ, Seck1 JR: Phenotypic analysis of mice bearing targeted deletions of 11 beta-hydroxysteroid dehydrogenases 1 and 2 genes. Mol Cell Endocrinol 2001, 171: 15-20

37. Tarutani M, Itami S, Okabe M, Ikawa M, Tezuka T, Yoshikawa K, Kinoshita T, Takeda J: Tissue-specific knockout of the mouse Pig-a gene reveals important roles for GPI-anchored proteins in skin development. Proc Natl Acad Sci U S A 1997, 94:7400-7405

38. Watanabe H, Gaide O, Petrilli V, Martinon F, Contassot E, Roques S, Kummer JA, Tschopp J, French LE: Activation of the IL-1betaprocessing inflammasome is involved in contact hypersensitivity. J Invest Dermatol 2007, 127:1956-1963

39. Honda T, Egawa G, Grabbe S, Kabashima K: Update of immune events in the murine contact hypersensitivity model: toward the understanding of allergic contact dermatitis. J Invest Dermatol 2013, 133:303-315

40. Gaffal E, Cron M, Glodde N, Bald T, Kuner R, Zimmer A, Lutz B, Tuting T: Cannabinoid 1 receptors in keratinocytes modulate proinflammatory chemokine secretion and attenuate contact allergic inflammation. J Immunol 2013, 190:4929-4936

41. Lim HY, Muller N, Herold MJ, van den Brandt J, Reichardt HM: Glucocorticoids exert opposing effects on macrophage function dependent on their concentration. Immunology 2007, 122:47-53

42. Itoi S, Terao M, Murota H, Katayama I: 11beta-Hydroxysteroid dehydrogenase 1 contributes to the pro-inflammatory response of keratinocytes. Biochem Biophys Res Commun 2013, 440:265-270

43. Slominski A, Wortsman J, Foecking MF, Shackleton C, GomezSanchez C, Szczesniewski A: Gas chromatography/mass spectrometry characterization of corticosteroid metabolism in human immortalized keratinocytes. J Invest Dermatol 2002, 118:310-315 